\title{
Influence of Plastic Mulching on Soil Moisture, Nutrient and Microbial Biomass in Pineapple Cultivation on Undulating Hilly Areas of Nagaland
}

\author{
Christy B. K. Sangma, A. Thirugnanavel ${ }^{1^{*}}$, Ph. Romen Sharma, G. Rajesha, and B.C. Deka ${ }^{2}$ \\ ICAR Research Complex for NEH Region, Nagaland Centre, Jharnapani, Medziphema-797 106, Nagaland, India \\ ${ }^{1}$ ICAR-Central Citrus Research Institute, Amravati Road, Nagpur - 440033, Maharashtra, India \\ ${ }^{2}$ ICAR-Agricultural Technology Application Research Institute (ATARI), Zone-VII, Umiam-793103, Meghalaya, India
}

\begin{abstract}
The pineapple var. Kew was planted on black polythene film mulching with double hedgerow planting to find out the influence of mulches on soil and plant. The soil samples were collected twice (kharif and rabi) at two different depths (0-15 and 15-30 cm), and the $\mathrm{pH}$, soil organic carbon (SOC), nitrogen, phosphorus, potassium, basal respiration and soil microbial biomass carbon were analysed. The data revealed that soil organic carbon and available $\mathrm{N}, \mathrm{P}$, and $\mathrm{K}$ content were slightly higher in the bottom hill than the top hill. The mulched field had higher nutrients than the non-mulched field. The fertility level varied slightly between the seasons. The biological parameters (microbial biomass carbon) were observed to be significantly higher $(\mathbf{P} \leq \mathbf{0 . 0 5})$ in the bottom hill in both the seasons than the non-mulched field. The soil moisture content ranged from $5.9 \%$ in March to $24.24 \%$ August in the bottom hill (15-30 cm depth). The moisture content in the non-mulched field was lower than the mulched field.
\end{abstract}

Key words: Plastic film mulch, soil moisture, soil organic carbon, hill region

\section{Introduction}

Pineapple [Ananas comosus (L.) Merr.], member of Bromeliaceae, a perennial herbaceous plant is one of the most popular tropical fruits in the world and rank third in world total fruit production (Makaranga et al. 2018; Silva et al. 2019). Besides fresh fruit, the fruits can also be canned and processed into different forms. In India, it is one of the leading fruit crops and is cultivated in about 1.03 lakh ha with a production of 17.06 lakh MT during 2017-18 (Anonymous 2018). It is commercially

*Corresponding author: (Email: lotus.thiru@gmail.com) cultivated in West Bengal, Assam, Manipur, Meghalaya, Nagaland, Tripura, Kerala and Karnataka. In Nagaland, pineapple is cultivated in an area of about 7060 ha with a production of 94,690 MT during 2017-18 (Anonymous 2018). Though the recommended slope of the terrain for pineapple cultivation should not exceed $5 \%$, pineapples are grown in selected hillocks up to the slope of 30-40\% or beyond in Nagaland. It is purely a rainfed crop under single row planting system which leads to more weed growth and high soil erosions during monsoons (Fig. 1).

Leaching of nutrients during the rainy seasons and low soil moisture stress during the winter season are the major constraints in Northeast Indian which affects 
the shallow-rooted crop like pineapple. Soil moisture is the most important factor in rainfed agriculture, and management of soil moisture is crucial for high production, particularly in rainfed agriculture. Mulching is the most adopted technology for conserving the soil moisture, reducing the erosion during monsoon, and to suppress the weed growth and improves the yield by 50 60 per cent in different fruit crops. The influence of

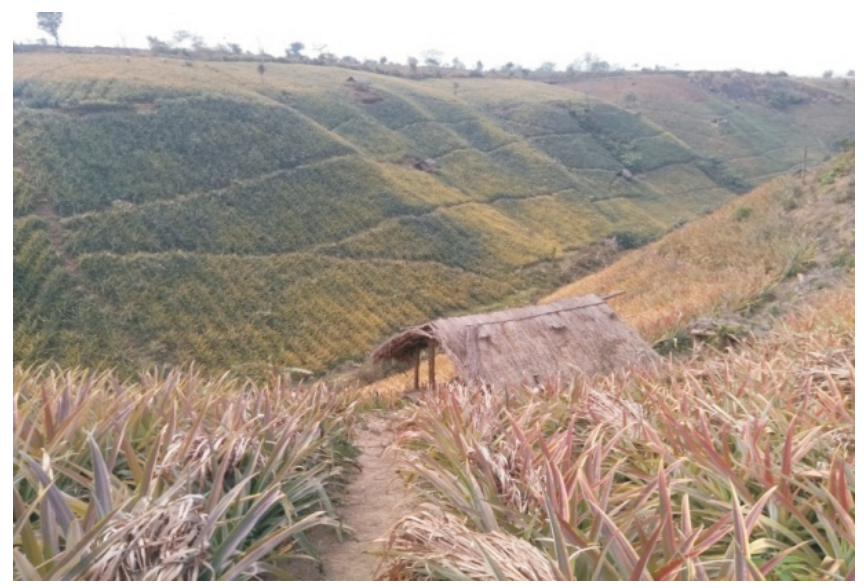

Fig. 1. Traditional pineapple cultivation

Materials and Methods

Experimental site

The experimental site was located at ICAR Nagaland Centre, Jharnapani, Nagaland $\left(25^{\circ} 45.321^{\prime \prime} \mathrm{N}\right.$; $\left.93^{\circ} 50.720^{\prime \prime} \mathrm{E}\right)$ at an altitude of $284 \mathrm{~m}$ above mean sea level. The area had a slope $>100 \%$ (Fig. 2). The plastic mulch (black polythene with 70-micron thickness) was laid in the slope and the pineapple var. Kew has been planted with double hedgerow $(90 \times 60 \times 30 \mathrm{~cm})$ during June 2013. For control, the pineapple has been planted without any mulch under double hedgerow planting. The study was carried out between July 2014 to August 2015. The experimental soil $(0-15 \mathrm{~cm})$ was sandy loam (Inceptisol) with a $\mathrm{pH}$ of 5.7.

\section{Sample collection}

The area was divided into two blocks, i.e. top hill area (higher side) and bottom hill area (foothill side) for soil sample collection at two different depths viz. 0$15 \mathrm{~cm}$ and $15-30 \mathrm{~cm}$. The samples were collected in three replicates. One half of each sample was stored at mulching on pineapple growth under sloppy condition is not documented though it is gaining popularity in recent past. Hence, the present study was carried out to study the effect of black polythene mulching and topography of planting on soil moisture conservation, soil chemical properties and soil microbial biomass in pineapple cultivation under double hedgerow planting (Fig. 2).

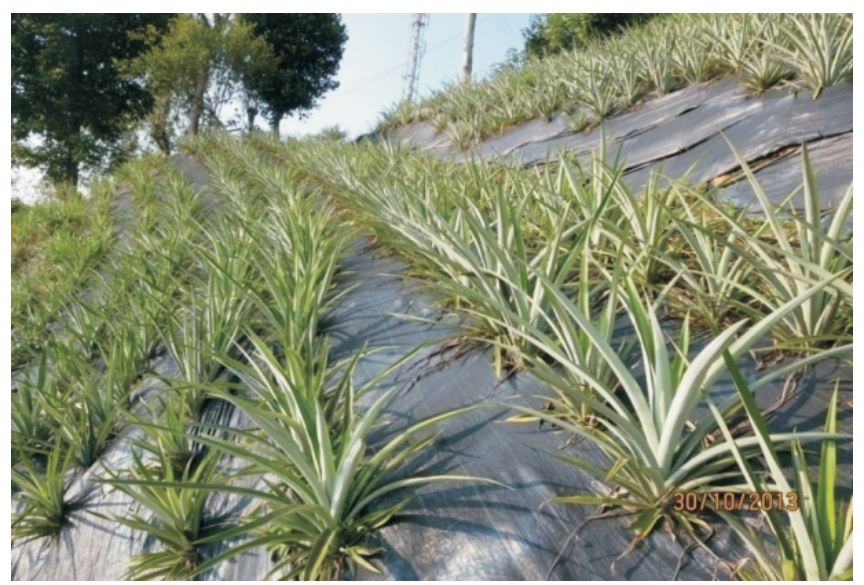

Fig. 2. Plastic mulching with double hedgerow

$4{ }^{\circ} \mathrm{C}$ for analysis of biological parameters $(0-15 \mathrm{~cm}$ soil only) and other half was used for chemical analysis. The sampling was carried out twice, i.e. kharif and rabi season.

\section{Soil chemical analysis}

Soil $\mathrm{pH}$ was analysed using 1:2.5 soil: water suspensions. Soil organic carbon (SOC) was determined by the wet oxidation method as described by Walkley and Black (1947). Available nitrogen (N) was determined by alkaline permanganate oxidation method as described by Subbiah and Asija (1956). Available phosphorus (P) was determined by the stannous chloride blue colour method (Bray and Kurtz 1945). The intensity of blue colour using Dickman Bray's reagent was measured at $660 \mathrm{~nm}$. Available potassium (K) was determined by Hanway and Heidel (1952) method. Gravimetric soil moisture content was determined by oven drying at $105^{\circ} \mathrm{C}$ to constant weight. This soil moisture content was recorded every 60 days interval for 1 year to observe the moisture conservation trend under the plastic film mulching. 


\section{Soil biological analysis}

Soil microbial biomass carbon (SMB-C) was determined by chloroform-fumigation-extraction method (Brookes and Joergensen 2006). To analyse SMB-C, $0.5 M \mathrm{~K}_{2} \mathrm{SO}_{4}$ (1:2.5 ratio) is used as the extractant and determined by the wet oxidation method. The difference in $\mathrm{C}$ content between fumigated and nonfumigated sub-samples was determined and calculated using a conversion factor, $\mathrm{K}_{\mathrm{EC}}=0.25$ (Jenkinson and Powlson 1976). Basal respiration (BAS) was measured by standard base trap method in a $\mathrm{NaOH}$ solution (Ohlinger et al. 1996; Pell et al. 2006).

\section{Results and Discussion}

The results showed that the chemical parameters of soils properties were higher in the mulched field than non-mulched filed in both the seasons (Table 1). During the Kharif season, soil pH was found to be significantly $(\mathrm{P} \leq 0.05)$ higher in the bottom hill under mulch than top hill and non-mulch conditions. The top layer $(0-15 \mathrm{~cm})$ in the bottom hill of mulched field recorded the $\mathrm{pH}$ of 4.59 , whereas the top hill recorded 4.25. The soil $\mathrm{pH}$ was very acidic (3.95) at 15$30 \mathrm{~cm}$ depth at the top hill. The soil organic carbon was slightly higher in 0-15 cm depth than $15-30 \mathrm{~cm}$ depth. It was higher at $0-15 \mathrm{~cm}$ depth $(2.13 \%)$ in the bottom hill of mulched field, and it was lower at $15-30 \mathrm{~cm}$ depth of the non-mulched field. The soil organic content (SOC), available nitrogen, phosphorous and potassium were in medium category at both the soil depths across the slopes. The bottom hill recorded a higher level of N, P, and $\mathrm{K}$ than the top hill and the non-mulched area at both the depths. This indicated that the run-off from the hill top brought the nutrients to bottom area in the mulched field, and in case of a non-mulched field, the nutrients were leached out. Black polythene mulching had a profound effect of keeping the nutrients in the soil, and it improves the soil condition, conserves moisture and nutrients, and reduces the run-off.

Table 1. Effect of black plastic film mulching on soil characteristics during Kharif season

\begin{tabular}{|c|c|c|c|c|c|c|c|c|}
\hline \multirow[t]{2}{*}{ Site with soil depth } & & \multirow[t]{2}{*}{$\mathrm{pH}$} & \multirow{2}{*}{$\begin{array}{c}\text { SOC } \\
(\%)\end{array}$} & $\mathrm{N}$ & $\mathrm{P}$ & K & \multirow{2}{*}{$\begin{array}{c}\text { BAS } \\
\mu \mathrm{gCO}_{2} \mathrm{~g}^{-1} \\
\mathrm{DW} \mathrm{hr}^{-1}\end{array}$} & \multirow{2}{*}{$\begin{array}{c}\text { SMB-C } \\
\mu \mathrm{g} \mathrm{g}^{-1} \\
\text { (DW) soil }\end{array}$} \\
\hline & & & & \multicolumn{3}{|c|}{$\mathrm{kg} \mathrm{ha}^{-1}$} & & \\
\hline \multirow[t]{2}{*}{ Top slope mulch } & $0-15$ & $4.25^{d}$ & $1.99^{\dagger}$ & $188.16^{b}$ & $4.12^{b}$ & 166.88 & \multirow{2}{*}{$0.094^{4}$} & \multirow{2}{*}{342.56} \\
\hline & $15-30$ & $3.95^{\mathrm{c}}$ & $1.81^{\mathrm{d}}$ & $178.75^{\complement}$ & $2.72^{c}$ & $156.80^{d}$ & & \\
\hline \multirow[t]{2}{*}{ Bottom slopemulch } & $0-15$ & $4.59^{\mathrm{a}}$ & $2.13^{\mathrm{a}}$ & 222.66 & $6.83^{\mathrm{a}}$ & $297.64^{R}$ & \multirow{2}{*}{$0.110^{2}$} & \multirow{2}{*}{502.56} \\
\hline & $15-30$ & $4.45^{\circ}$ & $1.93^{\mathrm{c}}$ & $191.30^{\circ}$ & $4.09^{\circ}$ & 246.68 & & \\
\hline \multirow[t]{2}{*}{ Non-mulch } & $0-15$ & 4.36 & $1.80^{d}$ & $172.48^{c}$ & 2.74 & 143.92 & \multirow[t]{2}{*}{$0.031^{\mathrm{b}}$} & \multirow[t]{2}{*}{$241.7 t$} \\
\hline & $15-30$ & $4.23^{\mathrm{d}}$ & $1.49^{\circ}$ & 159.94 & $2.46^{\mathrm{d}}$ & 133.28 & & \\
\hline $\mathrm{CD}(\mathrm{P}=0.05)$ & & 0.06 & NS & 6.83 & 0.08 & 4.90 & NS & 90.09 \\
\hline
\end{tabular}

Within a column, figures with the same letters do not differ significantly at $\mathrm{P} \leq 0.05$

During rabi season (Table 2), the soil $\mathrm{pH}$ ranged from 5.15 to 5.54 in the top $0-15 \mathrm{~cm}$, and it was slightly lower in the 15-30 cm depth. Further, it was observed that soil $\mathrm{pH}$ in rabi season was slightly lower than the kharif season. The change in soil $\mathrm{pH}$ between kharif and rabi was due to the movement of salts in the soil zones as the soil moisture moves up and down through the soil and the intense organic matter decay with the onset of warm temperature and rain (Brady and Weil 2007). The
SOC, $\mathrm{N}$ and $\mathrm{K}$ (except $\mathrm{P}$ ) content in rabi were found to be lower than the kharif season. The SOC (1.44\%), N (118.59 $\left.\mathrm{kg} \mathrm{ha}^{-1}\right), \mathrm{K}\left(188.64 \mathrm{~kg} \mathrm{ha}^{-1}\right)$ and P content (12.18 $\left.\mathrm{kg} \mathrm{ha}{ }^{-1}\right)$ during rabi season were significantly $(\mathrm{P} \leq 0.05)$ higher in the bottom hill than the top hill in both the mulched and non-mulched fields. This may be due to the accumulation of nutrients in the bottom hill by the movement of moisture from the top hill to bottom hill. The biological parameters like BAS and SMB-C were 
significantly higher $(\mathrm{P} \unlhd 0.05)$ in the bottom hill under the mulched field. This might be due to adequate soil moisture available for the living biomass to survive and multiply, in-turn giving the higher respirations.

Table 2. Effect of black plastic film mulching on soil characteristics during Rabi season

\begin{tabular}{|c|c|c|c|c|c|c|c|c|}
\hline \multirow[t]{2}{*}{ Site with soil depth } & & \multirow[t]{2}{*}{$\mathrm{pH}$} & \multirow{2}{*}{$\begin{array}{l}\text { SOC } \\
(\%)\end{array}$} & $\mathrm{N}$ & $\bar{P}$ & $\mathrm{~K}$ & \multirow{2}{*}{$\begin{array}{c}\text { BAS } \\
\mu \mathrm{gCO}_{2} \mathrm{~g}^{-1} \\
\mathrm{DW} \mathrm{hr}{ }^{-1}\end{array}$} & \multirow{2}{*}{$\begin{array}{c}\text { SMB-C } \\
\mu \mathrm{g} \mathrm{g}^{-1}(\mathrm{DW}) \\
\text { soil }\end{array}$} \\
\hline & & & & \multicolumn{3}{|c|}{$\mathrm{kg} \mathrm{ha}^{-1}$} & & \\
\hline \multirow[t]{2}{*}{ Top slope mulch } & $0-15$ & 5.29 & $1.04^{b}$ & $106.35^{b}$ & $9.11^{b}$ & $76.08^{\mathrm{e}}$ & \multirow{2}{*}{$0.092^{\mathrm{b}}$} & \multirow{2}{*}{$313.25^{b}$} \\
\hline & $15-30$ & 5.25 & $1.00^{\mathrm{b}}$ & $94.54^{\mathrm{c}}$ & $3.05^{\mathrm{d}}$ & $72.40^{\mathrm{f}}$ & & \\
\hline \multirow[t]{2}{*}{ Bottom slope mulch } & $0-15$ & 5.54 & $1.44^{\mathrm{a}}$ & $118.59^{\mathrm{a}}$ & $12.18^{\mathrm{a}}$ & $188.64^{\mathrm{a}}$ & \multirow{2}{*}{$0.154^{\mathrm{a}}$} & \multirow{2}{*}{$478.24^{\mathrm{a}}$} \\
\hline & $15-30$ & 5.37 & $1.38^{\mathrm{a}}$ & $105.18^{b}$ & $9.28^{\mathrm{b}}$ & $136.38^{\mathrm{c}}$ & & \\
\hline \multirow[t]{2}{*}{ Non-mulch } & $0-15$ & 5.15 & $0.61^{\mathrm{c}}$ & $77.28^{\mathrm{d}}$ & $4.33^{\mathrm{c}}$ & $166.50^{\mathrm{b}}$ & \multirow{2}{*}{$0.064^{\mathrm{c}}$} & \multirow[t]{2}{*}{$242.66^{\mathrm{c}}$} \\
\hline & $15-30$ & 5.00 & $0.46^{\mathrm{d}}$ & $63.36^{\mathrm{e}}$ & $3.37^{\mathrm{d}}$ & $94.10^{\mathrm{d}}$ & & \\
\hline $\mathrm{CD}(\mathrm{P} \leq 0.05)$ & & NS & 0.15 & 5.80 & 0.38 & 1.77 & 0.13 & 0.76 \\
\hline
\end{tabular}

Within a column, figures with the same letters do not differ significantly at $P \leq 0.05$

Soil moisture in the effective root zone is critical for plant growth and development. Low moisture stress during the winter season in Northeast India affects the growth and development of the crops. The plastic mulches reduce the vapour flow between soil surface and atmosphere thereby, reduces the evaporation (Bu et al. 2013). The moisture content observed every 60 days interval showed that the mulched field had higher soil moisture content than non-mulched fields (Fig. 3). The soil moisture content was slightly higher in $0-15 \mathrm{~cm}$ depth during the rainy season than $15-30 \mathrm{~cm}$ depth and vice-versa during dry seasons. The bottom hill recorded high moisture both in mulched and non-mulched field compared to top hill. During rainy season, a low level of differences was observed in the soil moisture status across the slope at $0-15 \mathrm{~cm}$ and $15-30 \mathrm{~cm}$ depths both in the mulched and non-mulched field. The highest soil moisture was observed during May to September (16.2 $18.11 \%$ at $0-15 \mathrm{~cm}$ and $21.5-20.2 \%$ at $15-30 \mathrm{~cm}$ in the top hill; $20.2-23.7 \%$ at $0-15 \mathrm{~cm}$ and $16.8-24.2 \%$ at $15-$ $30 \mathrm{~cm}$ in the bottom hill) and after that soil moisture content declined and became lowest during March (4.4 $\%$ at $0-15 \mathrm{~cm}$ and $5.1 \%$ at $15-30 \mathrm{~cm}$ in the non-mulched

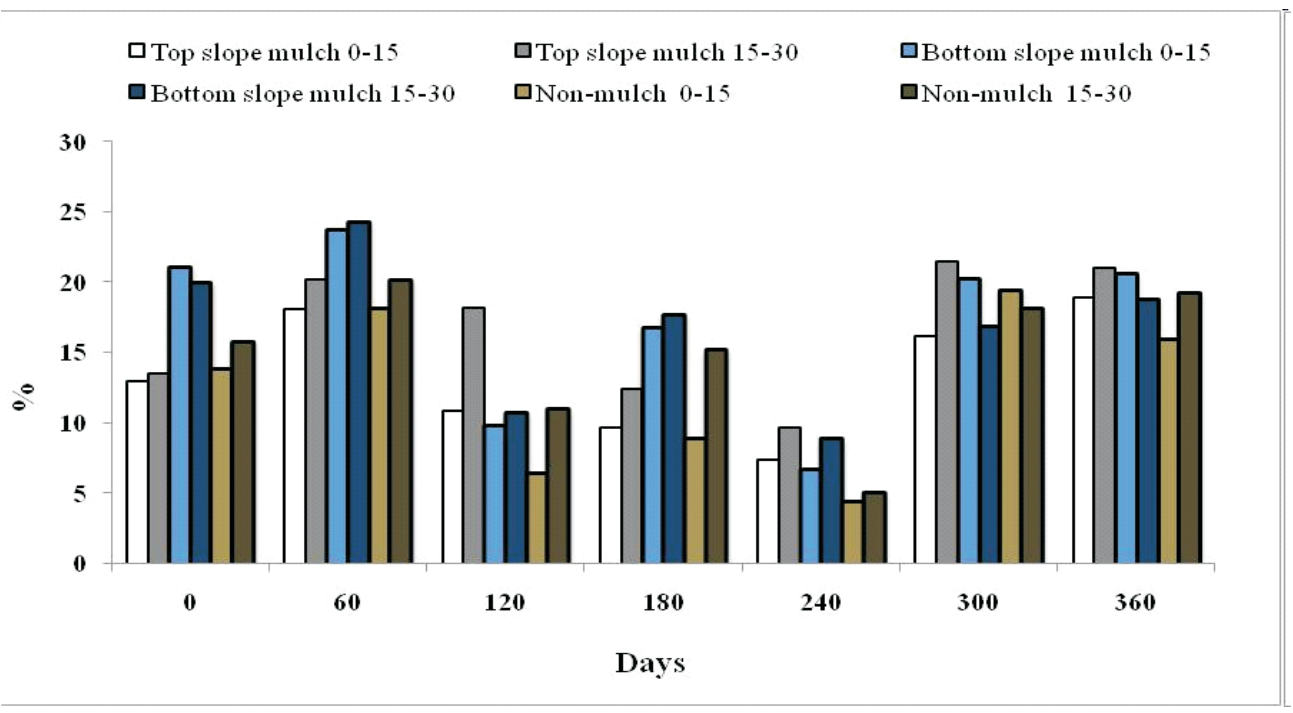

Fig. 3. Soil moisture content at every 60 days 
field and $9.71 \%$ and $8.9 \%$ at $15-30 \mathrm{~cm}$ in the top and bottom hill of mulched field). These results indicated that the plastic mulching conserved the soil moisture effectively. Further, it did not allow the excess moisture to allow inside the soil profile during the rainy season and it checked the soil moisture evaporation during the dry spell. Pineapple, being a shallow-rooted plant, its effective root zone lies at $15-45 \mathrm{~cm}$ depth (Bartholomew et al. 2003) performed better in the mulched field during the dry season due to good soil moisture content. Similar findings on the soil moisture conservation by plastic mulch were reported earlier Bu et al. (2013); Selim et al. (2013) and Jiang et al. (2016).

\section{Conclusion}

The leaching of soil nutrients during the rainy season and low moisture stress during dry season poses a great threat to pineapple growth. The results indicated that the black polythene mulch significantly improved the soil $\mathrm{pH}$, reduced the nutrient leaching, and conserved the soil moisture. The mulched field had higher basal respiration, soil microbial biomass carbon and soil moisture than the non-mulched field. Besides improving the soil properties, it arrested the weed growth completely. The key factors for the success of plastic mulch are affordable cost and easy availability in the market. The black plastic mulch is durable, economical, conserved the soil moisture, and helped the growth of the crop during a dry spell and could be used for commercial production of pineapple in Nagaland.

\section{References}

Anonymous (2018). Indian Horticulture Database. National Horticulture Board, Ministry of Agriculture, Government of India, Gurgaon, Haryana.

Bartholomew, D.P., Paull, R.E. and Rohrbach, K.G. (2003). The pineapple: botany, production and uses. (Eds. D. P. Bartholomew, R. E. Paull and K. G. Rohrbach). CABI Publishing, Wallingford, UK.

Brady, N.C. and Weil, R.R. (2007). In 'The nature and properties of soils'. 13 ${ }^{\text {th }}$ Edition. ( Eds. N.C. Brady and R.R. Weil). Upper Saddle River NJ, Pearson Prentice Hall.
Bray, R.H. and Kurtz L.T. (1945). Determination of total, organic and available forms of phosphorous in soils. Soil Science 59, 39-45.

Brookes, P.C. and Joergensen, R.G. (2006). Microbial biomass measurements by fumigationextraction. In 'Microbiological methods for assessing soil quality'. (Eds. J. Bloem, Hopkins, D. W. and A. Benedetti) pp. 77-83 (CABI Publishing, Oxfordshire: UK).

Bu, L.D., Liu, L.L., Zhua, L., Luo, S.S., Chen, X.P., Li, S.Q., Hill, R.L. and Zhao, Y. (2013). The effects of mulching on maize growth, yield and water use in a semi-arid region. Agriculture Water Management 123, 71-78.

Hanway, J.J. and Heidel, H. (1952). Soil analysis methods as used in Iowa state college, Soil Testing Laboratory. Iowa Agriculture 57, 1-31.

Jenkinson, D.S. and Powlson, D.S. (1976). The effects of biocidal treatments on metabolism in soil- $\mathrm{V}$ : A method for measuring soil biomass. Soil Biology and Biochemistry 8, 209-213.

Jiang, R., Li, X., Zhou, M., Li, H., Zhao, Y., Yi, J., Cui, L., Li, M., Zhang, J. and Qu, D. (2016). Plastic film mulching on soil, water and maize (Zea mays L.) yield in a ridge cultivation system on Loess Plateau of China. Soil Science and Plant Nutrition 62, 1-12.

Makaranga, A., Seth, M.S., Ndee, A., Mneney, E.E., Mbwambo, G., Lema, K., Godfrey, A., Mrema, L., Kachiwile, A., Mrema, E. and Msogoya, T.J. (2018). Diversity and genetic identity of pineapple [Ananas comosus (L.) Merr.] in Tanzania based on microsatellite markers. African Journal of Biotechnology 17, 811-817.

Ohlinger, R., Beck, T., Heilmann, B. and Beese, F. (1996). Soil Respiration. In 'Methods in Soil Biology'. (Eds. F. Schinner, R. Ohlinger, E. Kandeler and R. Margesin,) pp. 93-110. (Springer-Verlag: Berlin).

Pell, M., Stenstrom J. and Granhall, U. (2006). Soil respiration. In 'Microbiological methods for assessing soil quality'. (Eds. J. Bloem, D. Hopkins and A. Benedetti) pp. 300. (CABI Publishing, Oxfordshire: UK). 
Selim, T., Bouksila, F., Berndtsson, R. and Persson, M. (2013). Soil water and salinity distribution under different treatments of drip irrigation. Soil Science Society of America Journal 71, 11441156.

Silva, J.M., Lima, P.R., Souza, F.V., Ledo, C.A., Souza, E.H., Pestana, K.N. and Ferreira, C.F. (2019). Genetic diversity and nonparametric statistics to identify possible ISSR marker association with fiber quality of pineapple. Anais $d a$ Academia Brasileira de Ciências. e20180749. https://doi.org/10.1590/00013765201920180749

Subbiah, B.V. and Asija C.L. (1956). A rapid procedure for estimation of available nitrogen in soils. Current Science 25, 259-260.

Walkley, A. and Black, I.A. (1947). A critical examination of rapid method for determining organic carbo in soils- Effect of variation in digestion conditions and of inorganic soil constituents. Soil Science 63, 251-264.

Received: November, 2018 Accepted: March, 2019 